analogue of methionine, did not form the corresponding hydroxamate in the presence of the methionine-activating enzyme and did not inhibit methionine activation. The inability of the methionine-activating enzyme to use ethionine as a substrate is in contrast with the observed incorporation of radioactive ethionine into liver proteins (Levine \& Tarver, 1951) and into protein in Ehrlich ascites cells (Rabinovitz, Olson \& Greenberg, 1957). However, Rabinovitz et al. (1957) observed that less ethionine is incorporated into proteins than methionine, and this difference could account for the inability to demonstrate ethionine activation in isolated enzyme preparations.

\section{SUMMARY}

1. Rat-liver homogenate prepared in $0.25 \mathrm{M}$ sucrose was separated into particulate and supernatant fractions. The presence of an enzyme activating the carboxyl group of methionine could be demonstrated in the supernatant, but no such activity was found in a $0.05 \mathrm{M}$-potassium chloride extract of the particulate fraction.

2. The enzyme was inhibited by yeast ribonucleic acid, and by an enzymic hydrolysate of ribonucleic acid, by $20-30 \%$, but not by thymus deoxyribonucleic acid.

3. Glycylmethionine and alanylmethionine were activated by the enzyme preparation, but alanylmethionine activation was lower than that of methionine or glycylmethionine.
4. Inhibitors of protein synthesis (12 mMethionine, ribonuclease, protamine, 25 mM-sodium fluoride, 25 mM-sodium azide, $25 \mathrm{~mm}$-dinitrophenol) failed to inhibit the enzyme activity.

We are grateful to Dr P. N. Campbell and Dr O. Greengard for their help in the preparation of the paper, and to Miss B. Kernot for the preparation of the figures.

\section{REFERENCES}

Davie, E. W., Konigsberger, V. V. \& Lipmann, F. (1956). Arch. Biochem. Biophys. 65, 21.

Dische, Z. \& Schwartz, K. (1937). Mikrochem. Acta, $2,13$. Gale, E. F. (1955). Rapports 3 Int. Congr. Biochim., Bruxelles, p. 78.

Gornall, A. G., Bardawill, C. J. \& David, M. M. (1949). J. biol. Chem. 177, 751.

Hoagland, M. B. (1955). Biochim. biophys. Acta, 16, 288.

Hoagland, M. B., Keller, E. B. \& Zamecnik, P. C. (1956). J. biol. Chem. 218, 345.

Hoagland, M. B. \& Zamecnik, P. C. (1957). Fed. Proc. 16, 197.

Levine, M. \& Tarver, H. (1951). J. biol. Chem. 192, 835.

Rabinovitz, M., Olson, M. E. \& Greenberg, D. M. (1957). J. biol. Chem. 227, 217.

Rendi, R. (1955). Boll. Soc. ital. Biol. sper. 31, 1410.

Rendi, R. (1956). Congr. Soc. ital. Biol. sper.

Schweet, R. S. (1955). Biochim. biophys. Acta, 18, 566.

Sharon, N. \& Lipmann, F. (1957). Arch. Biochem. Biophys. 69, 219.

Zamecnik, P. C. \& Keller, E. B. (1954). J. biol. Chem. 209, 337.

Zamecnik, P. C., Keller, E. B., Hoagland, M. B. \& Littlefield, J. W. (1956). J. cell. comp. Physiol. 47, suppl. 1, p. 81 .

\title{
Studies on Plant Flavokinase
}

\author{
By K. V. GIRI, P. R. KRISHNASWAMY AND N. APPAJI RAO \\ Department of Biochemistry, Indian Institute of Science, Bangalore 3, India
}

(Received 27 November 1957)

As riboflavin is a component of several enzymes concerned with respiration, cells must be capable of synthesizing the active forms of the vitamin, namely both flavin mononucleotide and flavinadenine dinucleotide. The earlier observations (Hubner \& Verzar, 1939; Pulner \& Verzar, 1939), that phosphorylation of riboflavin could take place by means of inorganic phosphate in preparations of intestinal mucosa, seemed unlikely in view of the energetics of the reaction. A conclusive demonstration of the phosphorylation of riboflavin by adenosine triphosphate was made by Kearney \& Englard (1951), using a purified enzyme preparation from yeast. The only reports in the literature pertain to its isolation and purification from different yeasts (Kearney \& Englard, 1951; Giri \&
Krishnaswamy, 1956). Though the occurrence of riboflavin in plants is well known, little is known about the mechanism of synthesis of flavin nucleotides in plants. It was observed that synthesis of flavin mononucleotide took place in plant extracts when they were incubated under the same conditions as those used with yeasts (Giri, Krishnaswamy \& Appaji Rao, 1957). The properties of this plant enzyme have been investigated and are described in this paper.

\section{MATERIALS AND METHODS}

Substrates and reagents. Riboflavin and flavin mononucleotide (FMN) were products of Hoffman La-Roche and Nutrition Biochemicals Corp. respectively. Adenosine 


\section{Table 1. Progress of purification of flavokinase from Phaseolus radiatus}

For details of stages of purification see text. Reaction mixtures were as follows: $0 \cdot 2 \mathrm{ml}$. of riboflavin, $0 \cdot 1 \mathrm{mM} ; 0 \cdot 1 \mathrm{ml}$. of ATP, mM; $0.1 \mathrm{ml}$. of $\mathrm{NaF}, 0.1 \mathrm{M} ; 0.7 \mathrm{ml}$. of $0.1 \mathrm{M}$-veronal-HCl buffer (pH 8.6); $0.8 \mathrm{ml}$. of enzyme preparation from the various stages and $0.1 \mathrm{ml}$. of $\mathrm{MgSO}_{4}, 0.3 \mathrm{~mm}$. Total volume $2 \mathrm{ml}$. Incubated at $55^{\circ}$ for $1 \mathrm{hr}$.

$\begin{array}{ccccc}\begin{array}{c}\text { Stage of } \\ \text { purification }\end{array} & \begin{array}{c}\text { Volume } \\ \text { (ml.) }\end{array} & \begin{array}{c}\text { Protein } \\ \text { (mg.) }\end{array} & \begin{array}{c}\text { Total } \\ \text { activity } \\ \text { (units) }\end{array} & \begin{array}{c}\text { Specific activity } \\ \text { (units/mg. } \\ \text { of protein) }\end{array} \\ \text { I } & 165 & 15820 & 6198 & 0 \cdot 3908 \\ \text { II } & 180 & 4842 & 8246 & 1 \cdot 7030 \\ \text { III } & 60 & 820 & 6726 & 8 \cdot 2040 \\ \text { IV } & 130 & 416 & 5981 & 14 \cdot 5100 \\ \text { V } & 40 & 105 & 3144 & 29 \cdot 9300\end{array}$

triphosphate (ATP) used included preparations made according to LePage (1949), of purity 60-65\%, and one purchased from California Foundation for Biochemical Research of purity $95 \%$. Some differences in reactions were noted with samples of ATP of different purity but these differences were only quantitative in nature. All other chemicals used were of a reagent grade and the purest currently available.

Preparation and purification of enzyme. Finely powdered green gram (Phaseolus radiatus) was used as the source of the enzyme, and various procedures were tried to obtain extracts with maximum activity. Extraction of the powder at a temperature of $0-5^{\circ}$ with water was found to be more efficient than extraction with buffer solutions or with water at $25^{\circ}$ and $37^{\circ}$. The procedure finally adopted, which was very similar to that used by Kearney \& Englard (1951) for yeast flavokinase, was as follows.

Finely powdered material was extracted with water ( $100 \mathrm{~g} . / 300 \mathrm{ml}$.) for $60 \mathrm{~min}$. at $0-5^{\circ}$ by periodic shaking. The extract obtained by centrifuging at $1000 \mathrm{~g}(165 \mathrm{ml}$., stage I, Table 1) was dialysed in the cold against water for 18-20 hr. and the precipitate which appeared was centrifuged at $2500 \mathrm{~g}$. To the opalescent supernatant $(180 \mathrm{ml}$., stage II) ammonium sulphate to 0.40 saturation was added and precipitate obtained by centrifuging at $5000 \mathrm{~g}$ was dissolved in $50 \mathrm{ml}$. of water and dialysed for $18 \mathrm{hr}$. against water at $0-5^{\circ}(60 \mathrm{ml}$., stage III). An equal volume of alumina- $\mathrm{C}_{\gamma}$ gel $(15 \mathrm{mg} . / \mathrm{ml}$.) was added to the dialysed solution and kept for $20 \mathrm{~min}$. in the cold, and centrifuged at $1000 \mathrm{~g}$. This procedure removed much inactive protein; the precipitate was eluted three times with $10 \mathrm{ml}$. portions of 0.02 M-sodium phosphate buffer ( $\mathrm{pH} \mathrm{7.2)} \mathrm{and} \mathrm{recombined}$ with the supernatant (130 ml., stage IV). This was again fractionated with ammonium sulphate to 0.40 saturation; the precipitate obtained by centrifuging at $5000 \mathrm{~g}$ was dissolved in $30 \mathrm{ml}$. of $0.01 \mathrm{M}$-veronal-HCl buffer (pH 8.6) and the solution dialysed for $18 \mathrm{hr}$. against water in the cold (40 ml., stage V).

A 75-fold purification of the enzyme was achieved with a recovery of about $38 \%$. It is likely that crude extracts contain certain inhibitory factors which are eliminated on dialysis, since the activity increased on dialysis.

Enzyme assay. During the assay and analysis, tubes $(10 \mathrm{~cm} . \times 1 \mathrm{~cm}$.$) in which reactions were carried out were$ protected from light. The reaction mixtures, unless otherwise stated, consisted of $0.2 \mathrm{ml}$. of riboflavin solution, $0.1 \mathrm{mM} ; 0.1 \mathrm{ml}$. of ATP solution, $\mathrm{mM} ; 0.1 \mathrm{ml}$. of $\mathrm{NaF}$ solution, $0.1 \mathrm{M} ; 0.1 \mathrm{ml}$. of $\mathrm{MgSO}_{4}$ solution, $0.3 \mathrm{~mm} ; 0.7 \mathrm{ml}$. of $0.1 \mathrm{M}$-veronal-HCl buffer (pH 8.6) and $0.8 \mathrm{ml}$. of enzyme preparation; total volume, $2 \mathrm{ml}$. They were incubated at $55^{\circ}$ and at specified intervals, usually after $60 \mathrm{~min}$., the reaction was arrested by the addition of $0.8 \mathrm{ml}$. of $17.5 \%$ $(w / v)$ trichloroacetic acid. The tubes were kept in a boilingwater bath for $5 \mathrm{~min}$. to hydrolyse traces of flavin-adenine dinucleotide (FAD) formed. The solutions were cooled, centrifuged and suitable portions of the supernatant were analysed for FMN formed by the circular-paper-chromatographic method of Giri \& Krishnaswamy (1956), with butanol-acetic acid-water $(4: 1: 5, \nabla / v)$ as the solvent system. The procedure briefly consisted in locating FMN on the chromatograms under u.v. light, eluting the paper strips in glass-distilled water and measuring the fluorescence in a Klett fluorimeter. Appropriate blanks and controls were always run. For preparative purposes, the technique of Giri $(1954,1955)$ was used. Absorption spectra were determined with a Beckman Spectrophotometer, Model DU.

Riboflavin concentrations in germinating seedlings were determined by the method of Snell \& Strong (1939). Protein was determined by the Biuret method. One unit of enzyme activity is defined as the amount that synthesizes $1 \mu \mathrm{m}$-mole of $\mathrm{FMN}$ at $\mathrm{pH} 8 \cdot 6$, temperature $55^{\circ}$, in $60 \mathrm{~min}$.

\section{RESULTS}

Identification of flavin mononucleotide formed by enzymic synthesis. A reaction mixture $(40 \mathrm{ml}$.), containing the substrates, buffer, etc., as described was incubated for $18 \mathrm{hr}$. at $37^{\circ}$. The reaction was stopped with $16 \mathrm{ml}$. of $17 \cdot 5 \%(\mathrm{w} / \mathrm{v})$ trichloroacetic acid and the mixture was kept in a boiling-water bath for $5 \mathrm{~min}$. The supernatant was subjected to preparative circular-paper chromatography (Giri, 1954, 1955). The isolated product showed absorption maxima at 264-266, 372-374 and $446 \mathrm{~m} \mu$ and was chromatographically identical with an authentic sample of FMN. On enzymic hydrolysis by phosphatases $[0.2 \mathrm{ml}$. of $0.1 \mathrm{mM}-\mathrm{FMN} ; 0.8 \mathrm{ml}$. of $0.1 \mathrm{M}$-veronal-HCl buffer $(\mathrm{pH} \mathrm{8.6)}$ and $1 \mathrm{ml}$. of enzyme preparation from green gram], as well as acid hydrolysis with $\mathrm{N}-\mathrm{H}_{2} \mathrm{SO}_{4}$ at $100^{\circ}$ for $1 \mathrm{hr}$., phosphate and riboflavin were detected as degradation products.

Reverse reaction. FMN (0.2 $\mathrm{ml} ., 0.1 \mathrm{mM}) ; 0.1 \mathrm{ml}$. of $\mathrm{MgSO}_{4}, 0.3 \mathrm{~mm} ; 0.8 \mathrm{ml}$. veronal- $\mathrm{HCl}$ buffer (pH 8.6); and $0.9 \mathrm{ml}$. of the purest enzyme preparation (total volume $2 \mathrm{ml}$.) were incubated at 
$37^{\circ}$ for $2 \mathrm{hr}$. Reaction was arrested by the addition of $0.8 \mathrm{ml}$. of $17.5 \%(\mathrm{w} / \mathrm{v})$ trichloroacetic acid. Portions of supernatant were analysed chromatographically with butanol-acetic acid-water $(4: 1: 5$, $\mathrm{v} / \mathrm{v}$ ) as the solvent system. No riboflavin could be detected on the chromatograms. Kearney \& Englard (1951) have reported that the synthesis of FMN from riboflavin and ATP was virtually an irreversible reaction.

Optimum temperature for activity of enzyme. In preliminary experiments reactions were carried out at $37^{\circ}$. However, it was found later that the enzyme showed maximum activity at $55^{\circ}$ (Fig. 1 ).

The plant flavokinase was different from the yeast flavokinase in that it had a much higher temperature for optimum activity. Whereas the enzyme was totally inactivated when incubated alone at $60^{\circ}$, much activity $(90 \%)$ was retained when it was incubated with its substrates (riboflavin $0.1 \mathrm{~mm}$, ATP $1.0 \mathrm{~mm}$ ). This would explain to a certain extent the high temperature of optimum activity.

Progress curve of the reaction. This is shown in Fig. 2; $2 \mathrm{ml}$. reaction mixtures were set up under standard conditions as already stated. At different

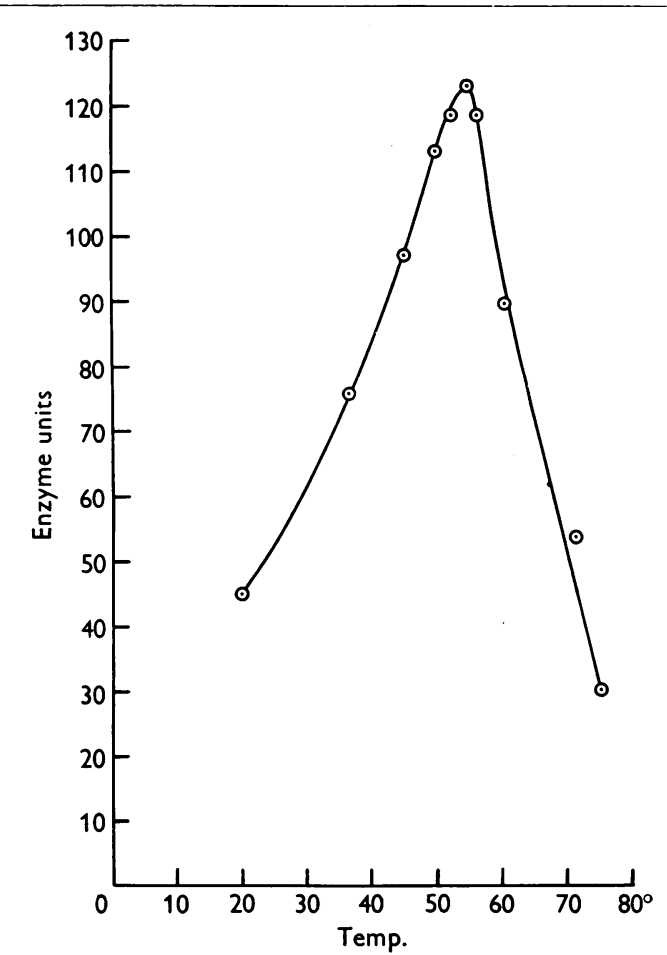

Fig. 1. Optimum temperature for activity of enzyme. Reaction mixtures contained: $0 \cdot 2 \mathrm{ml}$. of riboflavin, $0 \cdot 1 \mathrm{mM}$; $0.1 \mathrm{ml}$. of ATP, mM; $0.1 \mathrm{ml}$. of $\mathrm{NaF}, 0.1 \mathrm{M} ; 0.1 \mathrm{ml}$. of magnesium sulphate, $0.3 \mathrm{~mm} ; 0.7 \mathrm{ml}$. of $0.1 \mathrm{M}$-veronal-HCl buffer (pH 8.6); $0.8 \mathrm{ml}$. of enzyme; total volume $2 \mathrm{ml}$. Incubated for $1 \mathrm{hr}$. at various temperatures. intervals, they were analysed for FMN. Separate sets of tubes were used for each time interval.

pH-Activity curve. This is shown in Fig. 3. Variation of the initial rate of reaction as a function of $\mathrm{pH}$ was determined by carrying out experiments,

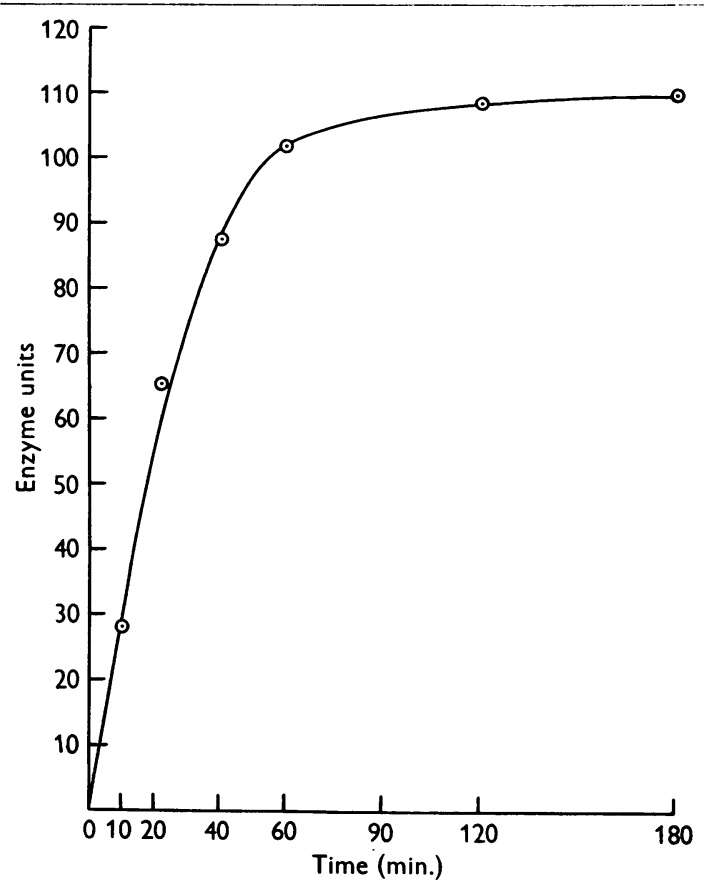

Fig. 2. Progress curve. Reaction mixtures were as in Fig. 1 and were incubated for $1 \mathrm{hr}$. at $55^{\circ}$ for the times indicated.

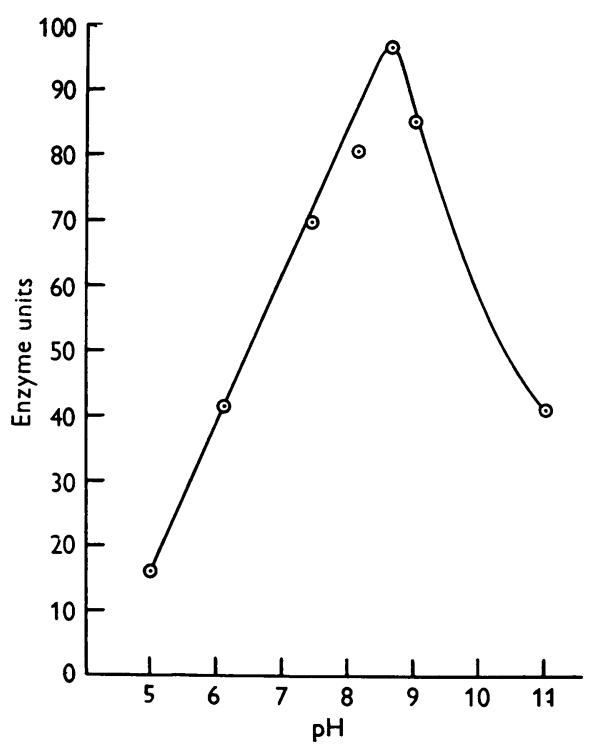

Fig. 3. pH-Activity curve. Reaction mixtures were as in

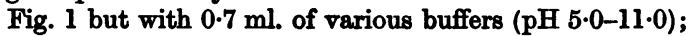
total volume $2 \mathrm{ml}$. They were incubated for $1 \mathrm{hr}$. at $55^{\circ}$. 
under conditions already specified, in different buffers of known $\mathrm{pH}$ [0.1 M-potassium hydrogen phthalate-NaOH (pH $4 \cdot 0$ and $5 \cdot 0$ ), $0 \cdot 1 \mathrm{~m}$-veronal$\mathrm{HCl}(\mathrm{pH} \mathrm{6.0-9 \cdot 0),} \mathrm{0.1} \mathrm{M-boric} \mathrm{acid-NaOH} \mathrm{(pH} \mathrm{10.0)}$ and $0 \cdot 1 \mathrm{M}$-potassium dihydrogen phosphate- $\mathrm{NaOH}$ $(\mathrm{pH} 11 \cdot 0)]$.

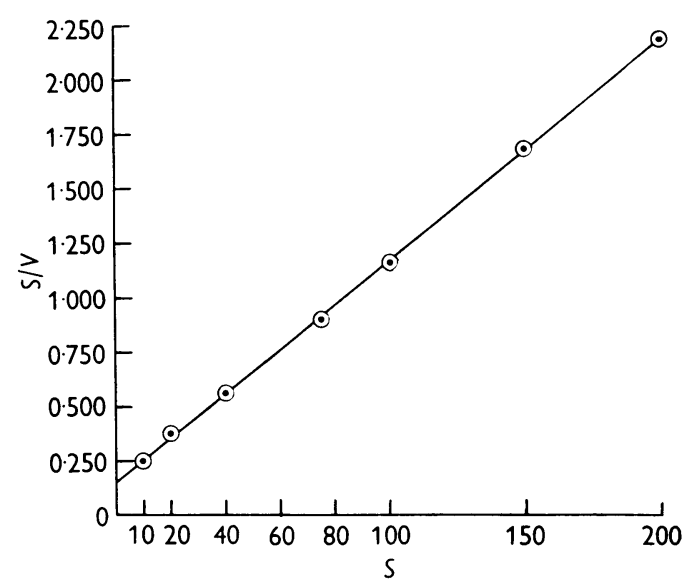

Fig. 4. Lineweaver-Burk plots. Reaction mixtures contained $\mathbf{0 . 2} \mathrm{ml}$. of riboflavin, of concentrations indicated in the graph; $0.1 \mathrm{ml}$. of ATP, mM; $0.1 \mathrm{ml}$. of $\mathrm{NaF}$, $0.1 \mathrm{M} ; 0.1 \mathrm{ml}$. of magnesium sulphate, $0.3 \mathrm{~mm} ; 0.7 \mathrm{ml}$. of veronal-HCl buffer (pH 8.6); and $0.8 \mathrm{ml}$. of enzyme; total volume $2 \mathrm{ml}$. The mixtures were incubated for $1 \mathrm{hr}$. at $55^{\circ} . S$, Concentration of riboflavin in reaction mixtures in $\mu$ moles; $V, \mu \mathrm{m}$-moles of FMN synthesized/ $2 \mathrm{ml} . / \mathrm{hr}$. at $55^{\circ}$ and $\mathrm{pH} 8 \cdot 6$.

Table 2. Effect of various ions on flavokinase activity

Reaction mixtures were as follows: $0.2 \mathrm{ml}$. of riboflavin, $0.1 \mathrm{mM} ; 0.1 \mathrm{ml}$. of ATP, mM; $0.1 \mathrm{ml}$. of NaF, $0.1 \mathrm{M} ; 0.7 \mathrm{ml}$. of $0.1 \mathrm{M}$-veronal-HCl buffer ( $\mathrm{pH} 8.6$ ); $0.8 \mathrm{ml}$. of enzyme preparation from stage III and the various ions as shown in Table 2. Total volume $2 \mathrm{ml}$. Incubated at $55^{\circ}$ for $1 \mathrm{hr}$. + , Activation; - , inhibition.

Percentage inhibition or activation of flavokinase activity at different concentrations of ions added

Calcium chloride Magnesium sulphate Zinc sulphate

Potassium cyanide

Lithium chloride

Manganese sulphate

Ferrous sulphate

Potassium permanganate

Copper sulphate

Nickel chloride

Cadmium sulphate

Cobalt acetate

Mercuric chloride
Various buffers such as veronal-HCl, borateboric acid, tris, phosphate and glycine were tried at pH 8.5. Maximum amount of FMN was synthesized with veronal-HCl buffer and this buffer has been used for enzyme assay.

Substrate affinity of enzyme. Lineweaver-Burk plots are shown in Fig. 4. At a constant ATP concentration, mM, different concentrations of riboflavin were used in the reaction system.

The enzyme functions at the maximum rate at a riboflavin concentration of $0.1 \mathrm{~mm}$. It was half saturated with riboflavin at a concentration of $0.015 \mathrm{~mm}$. At a constant riboflavin concentration of $0.1 \mathrm{mM}$, varying concentrations of ATP were used and it was observed that the enzyme functions at a maximum rate at an ATP concentration of $2 \mathrm{~mm}$.

Effect of various ions. A number of ions were tested for their effect on flavokinase activity. They were added to the system in different molar concentrations. In these experiments an enzyme preparation from stage III was used. The results are summarized in Table 2.

Of the ions used, $\mathrm{Mg}^{2+}$ activated the enzyme at all concentrations tested, $\mathrm{Mn}^{2+}$ and $\mathrm{Zn}^{2+}$ ions activated at low concentrations, but inhibited at higher concentrations. For routine assay of the enzyme $\mathrm{Mg}^{2+}$ ions were used as the activator. Kearney \& Englard (1951) used $\mathrm{Mg}^{2+}$ ions as the standard activator for yeast flavokinase since they observed that it was the most consistent in activating the enzyme, $\mathrm{Zn}^{2+}$ ions having a slight effect at some stages of purification and a much greater effect at other stages of purification. As suggested by Englard (1953), $\mathrm{Zn}^{2+}$ ions may affect the level of ATP in the system, thus resulting in a lowered synthesis of FMN.

$\mathrm{CN}^{-}, \mathrm{Hg}^{2+}, \mathrm{Fe}^{2+}, \mathrm{MnO}_{4}^{-}$and $\mathrm{Cu}^{2+}$ ions were found to be inhibitory, whereas $\mathrm{Ca}^{2+}, \mathrm{Ni}^{2+}, \mathrm{Li}^{+}$and $\mathrm{Cd}^{2+}$ ions were without effect. $\mathrm{Co}^{2+}$ ions were inhibitory at concentrations higher than mM. Hydroxylamine was also found to be an inhibitor.

Distribution of flavokinase activity in plants. Examination of a number of plants indicated that flavokinase activity was present in all of those plant materials examined (Table 3).

Germination and flavokinase activity. Riboflavin is one of the vitamins which not only occurs in fairly large amounts in plants but also increases considerably during germination (Bonner, 1942). Flavokinase activity during germination of Phaseolus radiatus was followed and riboflavin concentrations were also determined at the various stages (Fig. 5). Seeds were allowed to germinate in the dark, in Petri dishes. They were placed on moistened filter papers cut to the same size. Water was frequently sprinkled to keep the filter paper moist. At the end of definite intervals, they were taken 
out, homogenized in water $(1: 3, w / v)$, centrifuged and the supernatant obtained after dialysis of the crude extract was used as the enzyme. Riboflavin concentrations were determined on a parallel set of samples (Snell \& Strong, 1939). Increase in activity of the enzyme paralleled an increase in concentration of riboflavin.

\section{Table 3. Occurrence of flavokinase activity in different plants}

Reaction mixtures were as follows: $0.2 \mathrm{ml}$. of riboflavin, $0.1 \mathrm{mM} ; 0.1 \mathrm{ml}$. of ATP, $\mathrm{mM} ; 0.1 \mathrm{ml}$. of $\mathrm{NaF}, 0.1 \mathrm{M} ; 0.1 \mathrm{ml}$. of $\mathrm{MgSO}_{4}, 0.3 \mathrm{~mm} ; 0.7 \mathrm{ml}$. of $0.1 \mathrm{M}$-veronal-HCl buffer (pH 8.4); and $0.8 \mathrm{ml}$. of enzyme from stage II. Total volume $2 \mathrm{ml}$. Incubated at $37^{\circ}$ for $5 \mathrm{hr}$.

Plant source*

1. Cicer arietinum (Bengal gram)

2. Ricinus communis (castor seed)

3. Brassica campesteris (mustard)

4. Phaseolus mungo (black gram)

5. Phaseolus radiatus (green gram)

6. Dolichos lablab (field bean)

7. Dolichos biflorus (horse gram)

8. Canavalia gladiata (sword bean)

9. Pisum sativum (peas)

10. Sesamum indicum (sesame)

11. Cajanus indicus (red gram)

12. Solanum tuberosum (potato)

13. I pomea batatas (sweet potato)

* 1-11 were resting seeds.

$\dagger$ FMN synthesized at $37^{\circ}$ and pH 8.4 ( $\mu \mathrm{m}-\mathrm{moles} / 2 \mathrm{ml}$. of reaction mixture $/ 5 \mathrm{hr}$.).

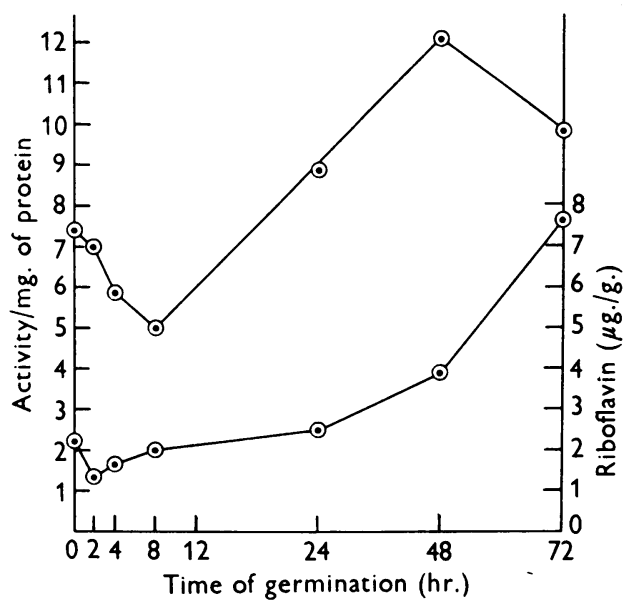

Fig. 5. Effect of germination on flavokinase activity. Flavokinase activity (top curve) and riboflavin content of green gram (Phaseolus radiatus) (bottom curve). Reaction mixtures were as in Fig. 1, and contained $0.8 \mathrm{ml}$. of enzyme in a total volume of $2 \mathrm{ml}$. and were incubated for $1 \mathrm{hr}$. at $55^{\circ}$.

\section{DISCUSSION}

The widespread occurrence of flavokinase activity in plants, as in yeasts, suggests that the main features of riboflavin metabolism are the same in plants as in yeast. Starting with riboflavin, flavin mononucleotide is synthesized by flavokinase by means of a reaction with adenosine triphosphate. The synthesis of flavin-adenine dinucleotide from riboflavin proceeds through the initial phosphorylation of riboflavin and subsequent interaction of flavin mononucleotide and adenosine triphosphate to form flavin-adenine dinucleotide by another enzymic step (Schrecker \& Kornberg, 1950). During the course of these investigations synthesis of flavin-adenine dinucleotide could be demonstrated in plant extracts. Though the occurrence of riboflavin in plants is well known (Bonner, 1942; Bonner \& Bonner, 1948; Watson \& Nogelle, 1947), information about the enzymes concerned in its metabolism is scanty. Riboflavin is a component of many flavoprotein enzymes present in plants. Hence a study of these two enzymes which synthesize the biologically active coenzyme forms of riboflavin from plant sources may help to delineate their role in the physiology of plants.

\section{SUMMARY}

1. Flavokinase activity has been detected for the first time in plants, and its properties were studied by the application of circular-paper chromatography. The plant investigated was Phaseolus radiatus.

2. Optimum $\mathrm{pH}$ for flavokinase activity was found to be 8.6 and temperature $55^{\circ}$; conversion into flavin mononucleotide was nearly $60 \%$. The Michaelis constant for riboflavin was found to be $0.015 \mathrm{~mm}$.

3. $\mathrm{Mg}^{2+}, \mathrm{Zn}^{2+}$ and $\mathrm{Mn}^{2+}$ ions showed an activating effect on flavokinase; $\mathrm{Zn}^{2+}$ and $\mathbf{M n}^{2+}$ ions, however, were inhibitory at higher concentrations. $\mathrm{Ca}^{2+}, \mathrm{Ni}^{2+}, \mathrm{Li}^{+}$and $\mathrm{Cd}^{2+}$ ions were without effect. $\mathrm{CN}^{-}, \mathrm{Hg}^{2+}, \mathrm{Fe}^{2+}, \mathrm{Cu}^{2+}, \mathrm{MnO}_{4}{ }^{-}$ions and hydroxylamine were inhibitory.

4. A 75-fold purification was obtained by fractionation with ammonium sulphate and adsorption with alumina- $\mathrm{C}_{\gamma}$. There was a parallel increase in riboflavin levels and flavokinase activity in germinating seedlings of Phaseolus radiatus.

\section{REFERENCES}

Bonner, J. (1942). Bot. Gaz. 103, 581.

Bonner, J. \& Bonner, H. (1948). Vitam. \& Horm. 6, 225.

Englard, S. (1953). J. Amer. chem. Soc. 75, 6048.

Giri, K. V. (1954). Nature, Lond., 173, 1194. 
Giri, K. V. (1955). J. Indian Inst. Sci. 37, 1.

Giri, K. V. \& Krishnaswamy, P. R. (1956). J. Indian Inst. Sci. 38, 232.

Giri, K. V., Krishnaswamy, P. R. \& Appaji Rao, N. (1957). Nature, Lond., 179, 1134.

Hubner, H. \& Verzar, F. (1939). Helv. chim. acta, 21, 2006.

Kearney, E. B. \& Englard, S. (1951). J. biol. Chem. 193, 821.
LePage, G. A. (1949). Biochem. Prep. 1, 5.

Pulner, R. \& Verzar, F. (1939). Enzymologia, 6, 333.

Schrecker, A. W. \& Kornberg, A. (1950). J. biol. Chem. 182 , 795.

Snell, E. E. \& Strong, F. M. (1939). Industr. Engng Chem. (Anal.), 11, 346.

Watson, S. A. \& Nogelle, G. R. (1947). Plant Physiol. 22, 228.

\title{
Initial Stages in the Biosynthesis of Porphyrins
}

\section{THE FORMATION OF $\delta$-AMINOLAEVULIC ACID FROM GLYCINE AND SUCCINYL. COENZYME A BY PARTICLES FROM CHICKEN ERYTHROCYTES*}

\author{
By K. D. GIBSON, $\dagger$ W. G. LAVER $\ddagger$ AND A. NEUBERGER \\ Department of Chemical Pathology, St Mary's Hospital Medical School, London, W. 2
}

(Received 5 March 1958)

It has been known for some time that the carbon skeleton of porphyrins can be synthesized in vivo entirely from glycine and a $\mathrm{C}_{4}$ compound which is an intermediate in the oxidative decarboxylation of $\alpha$-oxoglutarate to succinate (for review see Shemin, 1955). The discovery of the role of $\delta$ aminolaevulic acid in porphyrin synthesis (Shemin \& Russell, 1953; Neuberger \& Scott, 1953; Dresel \& Falk, 1953) led to the hypothesis that the initial reaction in porphyrin synthesis is the condensation of glycine with this $\mathrm{C}_{4}$ compound to form $\delta$-aminolaevulic acid, which is then further metabolized to porphobilinogen and porphyrins. The correctness of this view was demonstrated in Part 1 (Laver, Neuberger \& Udenfriend, 1958), which described the isolation and properties of a particulate system from erythrocytes of anaemic chickens that catalyses a net synthesis of $\delta$-aminolaevulic acid from glycine and $\alpha$-oxoglutarate or succinate.

However, the nature of the reacting $\mathrm{C}_{4}$ compound could not be determined in any of these investigations. Shemin \& Wittenberg (1951) suggested that it might be succinyl-coenzyme A (succinyl-CoA) even before the isolation of this substance by Sanadi \& Littlefield (1953); but little supporting evidence was obtained for this idea. Strong, but indirect evidence that coenzyme $A$ is involved in the synthesis of $\delta$-aminolaevulic acid comes from the study of haem and porphyrin formation in pantothenate-deficient ducks (Schulman \& Richert, 1957) and Tetrahymena vorax (Lascelles, 1957). Coenzyme A produces also a stimulation of activity in the system studied by Laver et al. (1958); but all

* Part 1: Laver, Neuberger \& Udenfriend (1958).

$\dagger$ Leverhulme Research Fellow.

$\ddagger$ Holder of Studentship of the Australian Commonwealth Scientific and Industrial Research Organisation. attempts to determine its role in this reaction were unsuccessful, and indeed no $\delta$-aminolaevulic acid was formed when synthetic succinyl-coenzyme $A$ was substituted for succinate or $\alpha$-oxoglutarate.

It has now been found that, if particles prepared according to Laver et al. are freeze-dried, they lose most of their capacity to form $\delta$-aminolaevulic acid from glycine and $\alpha$-oxoglutarate or succinate. However, when synthetic or enzymically generated succinyl-coenzyme $A$ is used as source of the $C_{4}$ compound, the formation of $\delta$-aminolaevulic acid is largely restored and it appears that succinylcoenzyme $A$ is indeed the reactive derivative of the $\mathrm{C}_{4}$ compound. Evidence has also been obtained which strongly implicates pyridoxal phosphate as a cofactor in this reaction. A preliminary report has appeared earlier (Gibson, Laver \& Neuberger, 1958).

\section{EXPERIMENTAL}

\section{Materials}

Succinyl-coenzyme A (succinyl-CoA) was synthesized according to Simon \& Shemin (1953); the product was kept at $0^{\circ}$ until required, and was always used within a few hours. Values quoted for succinyl-CoA concentrations are nominal only and represent the amount of coenzyme $A$ (CoA) used. Acetyl-CoA, propionyl-CoA and glutaryl-CoA were prepared similarly from the corresponding anhydrides and CoA. Crystalline glutamic dehydrogenase $[10 \mathrm{mg} . / \mathrm{ml}$., suspended in $40 \%$ saturated $\left(\mathrm{NH}_{4}\right)_{2} \mathrm{SO}_{4}$ ] was obtained from Boehringer und Soehne, Mannheim. $\alpha$-Oxoglutarate dehydrogenase was prepared according to Sanadi, Littlefield \& Bock (1952); the preparation used in this work was capable of oxidizing $0 \cdot 21 \mu$ mole of $\alpha$-oxoglutarate $/ \mathrm{min} . / \mathrm{mg}$. of protein, as measured by reduction of diphosphopyridine nucleotide (DPN) in the presence of mM-cysteine and excess of succinyl-CoA deacylase (Gergely, Hele \& Ramakrishnan, 1952). Crude succinic thiokinase was obtained from Escherichia coli (National Collection of Industrial 